\title{
Material Flow Analysis to Evaluate Supply Chain Evolution and Management: An Example Focused on Maritime Pine in the Landes de Gascogne Forest, France
}

\author{
Rory J. Layton ${ }^{1}$, Rachel Horta Arduin ${ }^{1, * \mathbb{C}}$, Haji Yazdeen ${ }^{1,2}$, Regis Pommier ${ }^{2}$ and Guido Sonnemann ${ }^{1} \mathbb{C}$ \\ 1 Université de Bordeaux, CNRS, Bordeaux INP, ISM, UMR 5255, F-33400 Talence, France; \\ rory.layton1@gmail.com (R.J.L.); askeefhaji@yahoo.com (H.Y.); guido.sonnemann@u-bordeaux.fr (G.S.) \\ 2 Arts et Métiers, Université de Bordeaux, CNRS, Bordeaux INP, UMR 5295, F-33405 Talence, France; \\ regis.pommier@u-bordeaux.fr \\ * Correspondence: rachel.horta-arduin@u-bordeaux.fr
}

check for updates

Citation: Layton, R.J.; Horta Arduin, R.; Yazdeen, H.; Pommier, R.; Sonnemann, G. Material Flow Analysis to Evaluate Supply Chain Evolution and Management: An Example Focused on Maritime Pine in the Landes de Gascogne Forest, France. Sustainability 2021, 13, 4378. https://doi.org/10.3390/su13084378

Academic Editors: Marc A. Rosen and Sara González García

Received: 18 February 2021

Accepted: 9 April 2021

Published: 14 April 2021

Publisher's Note: MDPI stays neutral with regard to jurisdictional claims in published maps and institutional affiliations.

Copyright: (c) 2021 by the authors. Licensee MDPI, Basel, Switzerland. This article is an open access article distributed under the terms and conditions of the Creative Commons Attribution (CC BY) license (https:/ / creativecommons.org/licenses/by/ $4.0 /)$.

\begin{abstract}
The Landes de Gascogne forest, located in southwestern France, spans nearly $10,000 \mathrm{~km}^{2}$ and consists largely of maritime pine (Pinus pinaster). This forest in unique to Europe because it is almost entirely created and managed by man for specific industries. On the basis of a material flow analysis, we assessed the upstream supply chain of maritime pine from 2013 to 2019, using a cradle-to-gate approach. The assessment is based on data provided by Alliance Forêts Bois, an important stakeholder of the region and leader in the production of forest resources in France. For various reasons, the harvest totals decreased $10 \%$ in the last years. We identified a clear orientation to specific industries-in 2019,45\% was used as pulpwood. This is due to the overall design of the current territory, species of tree, and market values of the pulp and paper industry. The current design provides a limited supply of old growth trees, which produce high-quality logs for construction-based products, and are also more resistant to climate variability. A future shift or balance in raw material flows could be a crucial step in protecting the long-term economic viability of the region. This article aims to contribute to new attempts in providing comprehensive views of stocks and flows in the French forest-wood supply chain.
\end{abstract}

Keywords: material flow analysis; wood; production; raw materials supply; sustainable regional development

\section{Introduction}

Forests provide different ecosystem services, attending economic, social and environmental purposes. They provide a basis for economic and social development through forestry, logging activities and wood-based industries, as well as through tourism and hunting [1]. From the environmental perspective, forestry and forest management contributes to reducing the risk of natural disasters and climate change. These attributes are often highlighted in political and strategic amendments such as the second commitment period of the Kyoto Protocol, the Paris Agreement on climate change, and the Sustainable Development Goals (SDGs) [2,3]. More specifically, t SDG 15 (life on land) is directed to forests and calls for their restoration, protection and sustainable use and management [4]. Wood-based products play a pivotal role in the development of bioeconomy regions and this transition in production must develop sustainably without negative effects to the environment or society.

The regional perspective is essential when weighing the social life cycle assessment indices and implications of products, as these are dependent on national and regional socioeconomic conditions [5]. Further, sustainable transitions made at the regional level, which incorporate methodologies and tools based on life cycle thinking and cascade mapping are crucial. In this context, Ioannidou et al. presented a framework to evaluate the 
risks in the construction wood product system through a criticality assessment framework [6]. Life cycle approaches can systematically support sustainable socioeconomic development at the regional level [7]. Some life cycle assessment was made by Pommier et al. concerning the engineered wood products from maritime pine trees [8,9].

In the near future (up to 2030) the global demand for the services of wood is expected to increase due to population growth and regulations promoting renewable energy and the adoption of bioeconomy strategies [10]. To date, accurate and comprehensive tools that map the global environmental and socioeconomic impacts due to biomass use are unavailable. The quantification of proposed indicators can provide sector, regional and transnational insights specific to the wood-based economy [11,12].

Across the European Union (EU), there is a wide variety of forests totaling about 182 million hectares, $43 \%$ of the EU's land area. In 2015, Sweden, Spain, Finland, France, Germany and Italy accounted for two-thirds of the EU's total forested areas. Wood is still the main source of financial revenue from forests, and its demand is rapidly growing [13]. Wood serves as a raw material for a wide range of products and is also used for energy purposes [14]. In the EU, Germany has the largest stock of timber (3.7 billion $\mathrm{m}^{3}$ or $13.7 \%$ of the EU total), followed by Sweden and France [1].

In 2013, the European Forest Strategy highlighted the need to increase the understanding of the complex environmental and societal challenges that the forest sector is facing [13]. Mapping and assessing the state of forest ecosystems and their services is important to understand the current state of regional forests and how they are evolving. Compiling forest inventory data is vital to the success of efforts to assess forest-based resource availability [15]. Comprehensive forest design and management is also crucial in combating specific weather events such as drought and windthrow. The role of wind as a driver of raw material flows also depends on how frequently these weather events occur within more vulnerable regions, such as the Landes de Gascogne forest. This recurrent natural disturbance offers acute and often chronic effects on forests, which drives ecosystem patterns and processes [16]. Another aspect strongly promoted in bioeconomy strategic policies is the need for the effective cascading of woody biomass, aiming to promote resource-efficiency and circular use [17]. More specifically, the cascading use of wood can effectively guide an enhanced regional resource use, while also decreasing greenhouse gasses [18].

At a global level, Bais et al. (2015) assessed the wood biomass flows in 11 world regions from 1990 to 2010 [10]. The global forest productivity is increasing about 7\% per year, while extraction remains stable. The authors highlighted the uncertainties on wood flows, especially of wood fuels. Other studies have focused on regional levels, like Mantau (2015) in Germany [19], Kayo et al. (2019) in Japan [12] and Lenglet et al. (2017) in France [20]. In France, 31\% of land area is covered by forest [1]. Lenglet et al. focused on the forest-wood supply chain in metropolitan France, and the scope of assessment included the upstream part of the supply chain and the transformation of lumber, industrial wood and pulpwood. The assessment allowed for an overview of flows for hard and soft roundwood, industrial wood and pulpwood, including imports and exports. The results bring interesting insights to support policy and improve the development of the national wood supply chain. However, this study only provided a snapshot of the situation for a specific reference year and did not capture trends or details on supplemental species.

In this context, our study presents complementary data for the studies developed on the national and EU level, with a regional focus in one majority species of softwood. The Landes de Gascogne forest, located in southwestern France (see Figure 1), has an afforestation rate of over $70 \%$, largely due to a concentration of monospecific stands of maritime pine (Pinus pinaster) [21].

Landes de Gascone is originally a sandy soil of alternating dunes, wetlands and grass. It is located in front of the Bay of Biscay; thus, the oceanic climate of the region results in important precipitations (more than $1200 \mathrm{~mm}$ /year), except in summer when the sand dries the soil. The poorness of the sandy soils of the Landes plateau and the high levels of its water table leave few competitors to the maritime pine's frugality and versatility [22]. 


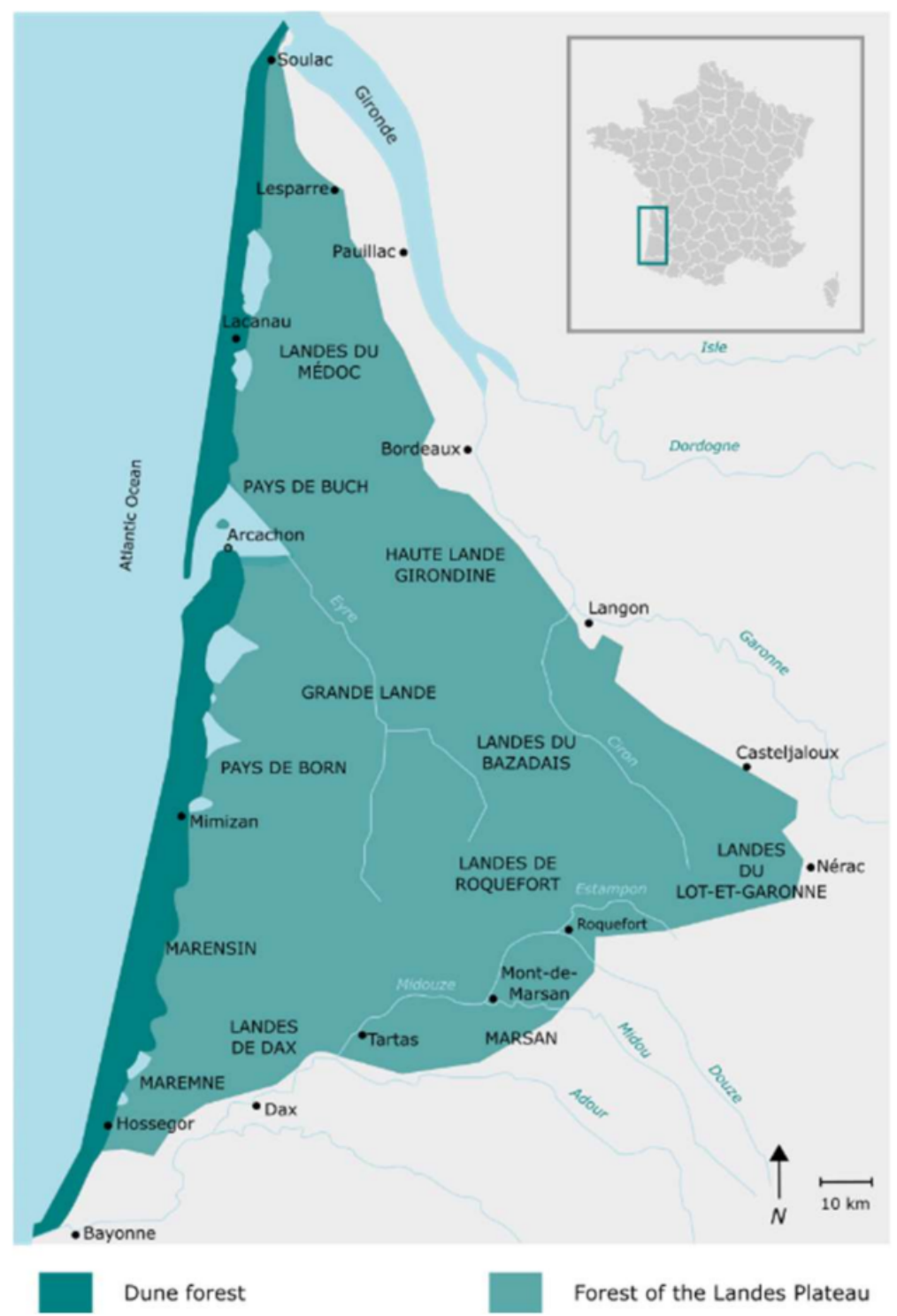

Figure 1. Location of Landes de Gascogne forest.

Landes de Gascogne forest in unique to Europe because it is almost entirely created and managed by man for specific industries. This forest was planted first to contain littoral dunes in the middle of the 19th century. The trees were then utilized for their resins and the forest was further developed and planted inward by Napoleon III. From the harvest of resin to maintain wooden ships, to the use of turpentine for lanterns and light, to the production of timber for mining and railway infrastructure, the economic applications of this unique forest have evolved throughout the years, fueled by market changes. Currently, the regional raw material flow of timber resources rests within market pulp and wood packaging. The harvesting technique is machinery harvesting only. The machine cut the trees in $2.5 \mathrm{~m}$ logs (100 inches). Today, the production of wood, populated only with maritime pine, occupies 897,000 hectares out of the 1,166,000 hectares of the Gascony forest. The rest $(269,000$ hectares) is shared between the coastal protection zone and about 100,000 hectares of oaks and various other species [13]. The majority of the forest is PEFC (Programme for the Endorsement of Forest Certification) certified. The production and allocation of timber products has never been static throughout its history, and moving forward into the future, this resource may pivot once again [14].

The management of the Landes de Gascogne forest is a key challenge for the sustainable development in the New Aquitaine Region. In this context, the goal of this work is 
to assess the upstream supply chain of wood-based products in the Landes de Gascogne region from 2013 to 2019, with a focus on maritime pine (Pinus pinaster). Predictive forest design planning must be supported on the basis of the current and future market needs in the context of a circular economy. This assessment aims to support decision-making and improve forest design, aiming for the effective cascading of woody biomass to promote an efficient and circular use of resources.

\section{Materials and Methods}

\subsection{Material Flow Analysis (MFA)}

MFA is a systematic assessment of the flows and stocks of materials within a system defined in space and time [23,24]. New developments and expansions in industrial research fields emphasize the importance of MFA methods to generate a meaningful understanding of specific system functions. It can also support decision makers, particularly in the expanding field of environmental policy. However, one main limitation of MFA is the lack of data, or its high degree of uncertainty $[25,26]$.

Our paper analyzes the upstream of the forest-wood supply chain using a cradle-togate approach. By primarily focusing on upstream services and allocation, we can form an appropriate visualization of the beginning of this product stream. It covers all coniferous softwood log products, with an emphasis on wooden pallets, sawnwood, plywood, pulp and paper, as well as energy wood, sawmill residues and other niche products. Products with a cumulative average stream of less than $10,000 \mathrm{~m}^{3} /$ year were excluded from the figure unless stated otherwise in this study.

Consequently, the MFA model used does not focus on the second or third transformation industries, for example, the furniture industry and specific construction sectors. Furthermore, because of the nature of the Landes de Gascogne region, this paper highlights the allocation of primarily maritime pine. However, it is known that other coniferous softwoods like white, red and Corsican pine, as well as miscellaneous and undetermined pine, are also produced in the region. The other coniferous softwoods represent less than $1 \%$ of yearly harvests, and because of limits on the database used in the study, they could not be split from the flows of maritime pine.

The main purpose of this work is to detail the physical flows of timber. Further, a first economic assessment of the supply chain was included considering the prices of the different co-products generated.

\subsection{Reference Unit}

The wood fiber equivalent was used as the reference unit. This unit was used in comparable studies in other European countries $[19,27,28]$. The name " $\mathrm{m}^{3}$ of fiber equivalent" was taken from Weimar (2009) [28] and Bösch et al. (2015) [27], while Mantau et al. (2010) [19] and the forest department of UNECE/FAO [29] use the term "solid wood equivalent". The main advantage of using $\mathrm{m}^{3}$ of fiber equivalent compared to a mass unit is that it is equivalent to $\mathrm{m}^{3}$ of roundwood in the case of greenwood (e.g, wood increment, harvest).

The wood fiber equivalent (referred to as $\mathrm{m}^{3}$ [f] in the text) is the volume of the wood fibers that are contained in the product at the fiber saturation point to take into account the swelling and shrinking of wood fibers [28]. For each wood-based product (e.g., fiber board, plywood, pulp, etc.), a specific conversion factor was calculated depending on its primary measurement units.

\subsection{Visualization and Software}

Complementary to the data spreadsheets, the software utilized for this analysis was e!Sankey $5^{\circledR}$. Sankey diagrams allow users to depict any kind of flow-energy, material or cost flows, for example-in the form of an arrow. The thickness of the arrow directly reflects the relative flow volume, i.e., a flow with twice the volume as another is indicated by an arrow twice as wide. The goal of visualizing flows with Sankey diagrams is to identify inefficiencies, potentials for savings or establishing added value. Sankey 
diagrams are gaining increasing importance, especially in the context of growing demand for more efficient technologies. They can also be a helpful instrument in the business sector, since production systems, including their technical and economical inter-relationships, are becoming increasingly complex, and therefore, must be represented in an intelligible way [30].

\subsection{Primary Data}

Alliance Forêts Bois provided access to their database including information on the physical flows of wood products from different types of species (e.g. maritime pine, corsican, poplar and douglas-fir, as well as red and white pine) and their customers. Alliance Forêts Bois is a French cooperative group, originally from the Landes de Gascogne forest, whose porfolio occupies the western half of France and has positioned itself in the last decade as a national leader in the production and mobilization of forest resources. The data represent more than $30 \%$ of the harvested maritime pine in the considered region [31]. This database is representative of the regional harvesting, as the use of maritime pine is dependent on its overall quality. Since this variety is a monoculture, the collected data can be representative of a wider harvest area. Overall, $80 \%$ of maritime pines' material viability is due to the internal tree variation of quality [32]. The remaining part (20\%) is directed by the quality of the soil. The database utilized is geographically constant and independent to different harvests in one territorial zone.

Considering the scope of this study, only data regarding maritime pine and centering in the Landes de Gascogne region were considered. Thus, before analyzing the data, it was necessary to extract the data applicable to the scope of the study. For example, in relation to geographical scope (Landes de Gascogne region), only data from customers with zip codes beginning with 33, 40 and 47 were considered. This flow does not represent the exact processing flow on the wood or fibers, but is a highlight of the upstream product delivery and divisions of the raw material.

\section{Results and Discussion}

\subsection{Wood Flow Analysis}

The results of the maritime pine supply chain in France, considering a cradle-to-gate approach, are presented in the following paragraphs and figures. They aim to present a yearly summary of the upstream part of the supply chain (forest stock, energy wood, industrial, processed) from 2013 to 2019. Every flow specifies the quantity of wood in $\mathrm{m}^{3}$ (f) fiber equivalent, simplified as $\mathrm{m}^{3}$, as well as main product percentages above $5 \%$.

Figure 2 presents the total amount of maritime pine harvested in 2019 and the flows consumed by different sectors: lumber, industrial and fuel. The last assessment level of the Sankey graph presents the application to the different products associated with the three industries.

In 2019, the difference between lumber and industrial wood allocation was almost balanced and equal, with $43 \%$ of timber allocated to lumber and $45 \%$ allocated to industrial wood. Among the flows destined for lumber production, 10\% was for canter logs and $15 \%$ was allocated to wood packaging. Only $14 \%$ of the total harvest was dedicated to the construction sector in the form of high-quality logs $(6 \%)$ and plywood (8\%). High-quality logs are further processed into flooring, siding and joinery. The limited use for higher quality applications is due to the high amount of knots and the general slope of the grain; therefore, it is not considered as standard wood for timber. Fuelwood represented a total of $11 \%$ of the flow, with a majority of this being shredded fragments and grey softwood.

Table 1 summarizes the amount of wood harvested in Landes de Gascogne forest from 2013 to 2019. As seen, there is a very large difference between the amount harvested in 2013 and in 2019 (34\% decrease in volume yield) and this can be attributed to major wind hazards that occurred in the region in 2009. This devastating windstorm in the Landes de Gascogne region resulted in a catastrophic loss of around 50\% of the maritime pine. This species, when relatively young, are highly vulnerable to weather events. The harvest year 
of 2013 signaled the final year that the downed trees from this weather event in 2009 were harvested, which explains the high harvest.

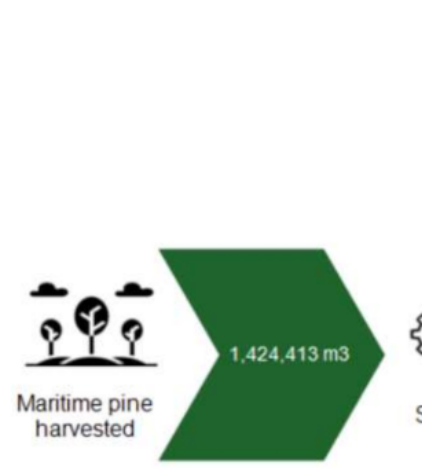

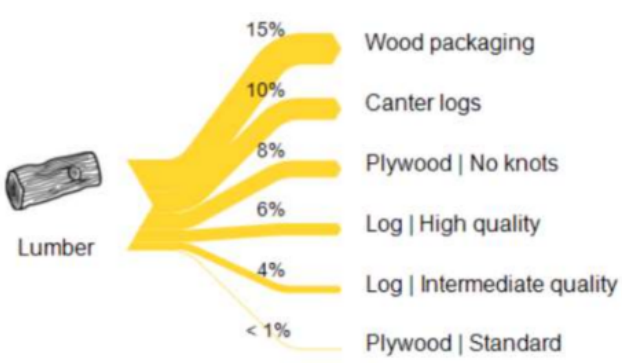
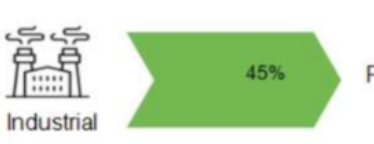

Pulpwood
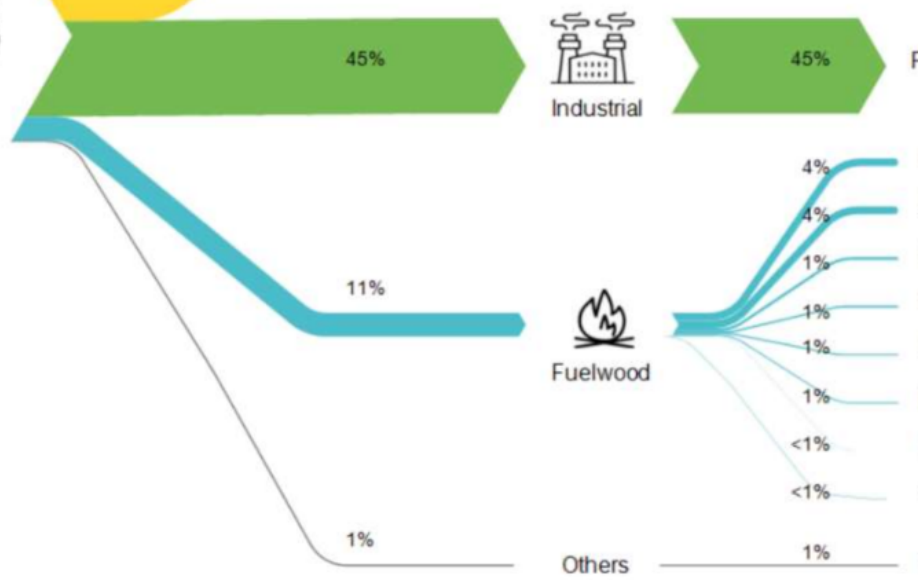

Gray softwood

Shredded fragments

Shredded wood

Others

Sawdust

Mixed products unspecified

Biomass

Green pulpwood

Processed wood

Figure 2. Cradle-to-gate maritime pine flows in 2019: upstream section of forest wood.

Table 1. Amount of maritime pine harvested in Landes de Gascogne forest.

\begin{tabular}{cccccccc}
\hline $\begin{array}{c}\text { Year/Harvesting } \\
\left(\mathrm{m}^{3}\right)\end{array}$ & 2013 & 2014 & 2015 & 2016 & 2017 & 2018 & 2019 \\
\cline { 2 - 7 } & $2,148,870$ & $1,939,673$ & $1,927,107$ & $1,615,665$ & $1,651,905$ & $1,424,482$ & $1,424,413$ \\
\hline
\end{tabular}

Similar to the approach presented in Figure 2, the total amount of maritime pine harvested in 2013 and the flows consumed by different sectors are shown in Figure 3. In $2013,50 \%$ of the timber harvested was delivered for lumber purposes, and $43 \%$ was for industrial wood (mostly for pulpwood). The majority of lumber was generated into canter $\operatorname{logs}(13 \%)$ and wood packaging $(21 \%)$. These materials were then used to produce cardboard, which is, at the moment, a growing industry in the EU. Concerning the construction sector, the allocation of timber in 2013 and 2019 is quite similar. Therefore, despite the massive difference in harvest between these two years, the same amount of no-knot plywood and high-quality log reserved for construction applications were relatively the same. This is most likely attributed to a primary focus on market pulp, a lack of high-quality construction lumber and an absence of material sourcing or partnerships to clients in the construction sector.

Figure 4 presents the evolution of the different products from 2013 to 2019. The pulpwood allocation amount has been systematically decreasing since 2013. However, a large increase of close to $100,000 \mathrm{~m}^{3}$ can be seen for 2019 . 


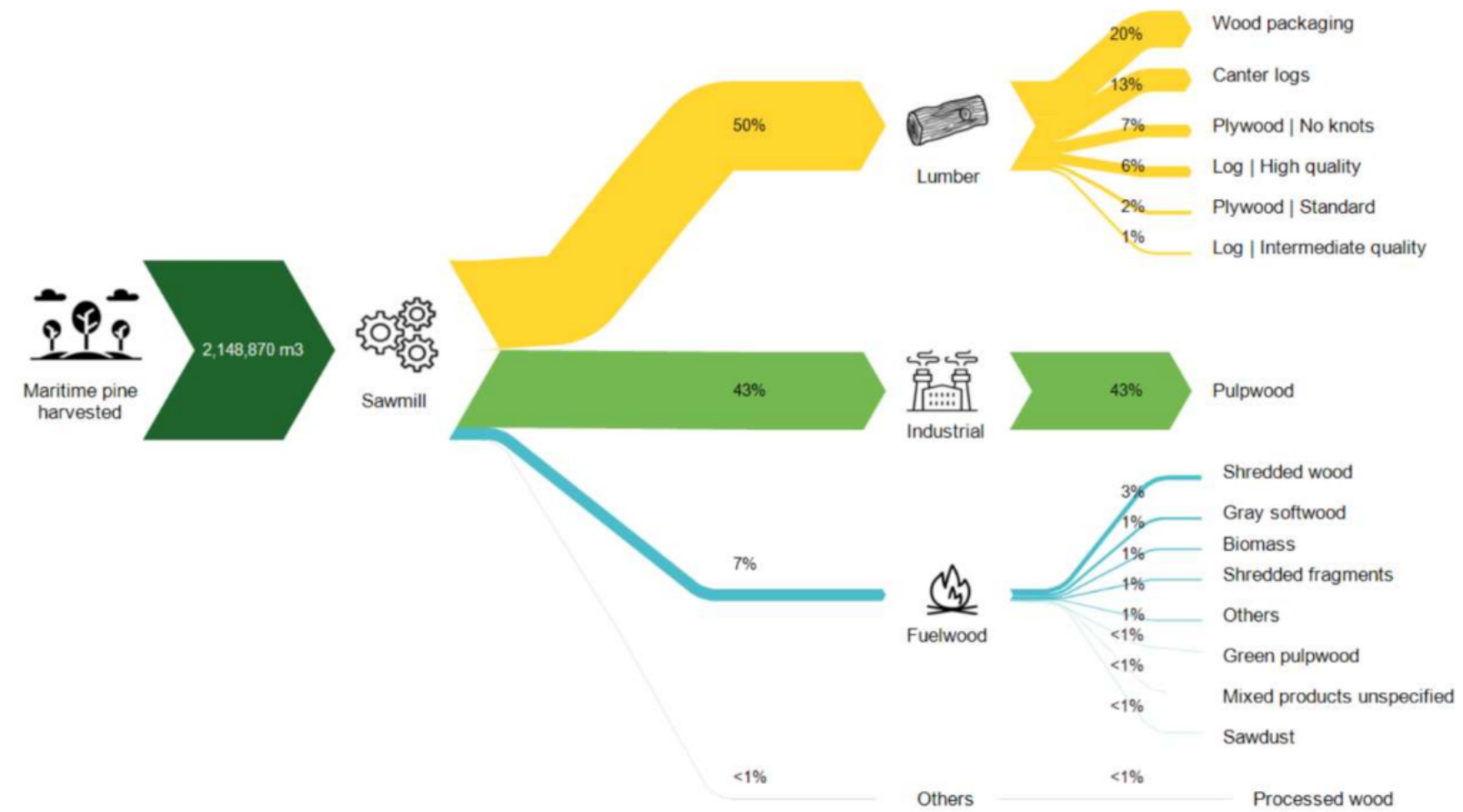

Figure 3. Cradle-to-gate maritime pine flows in 2013: upstream section of forest wood.

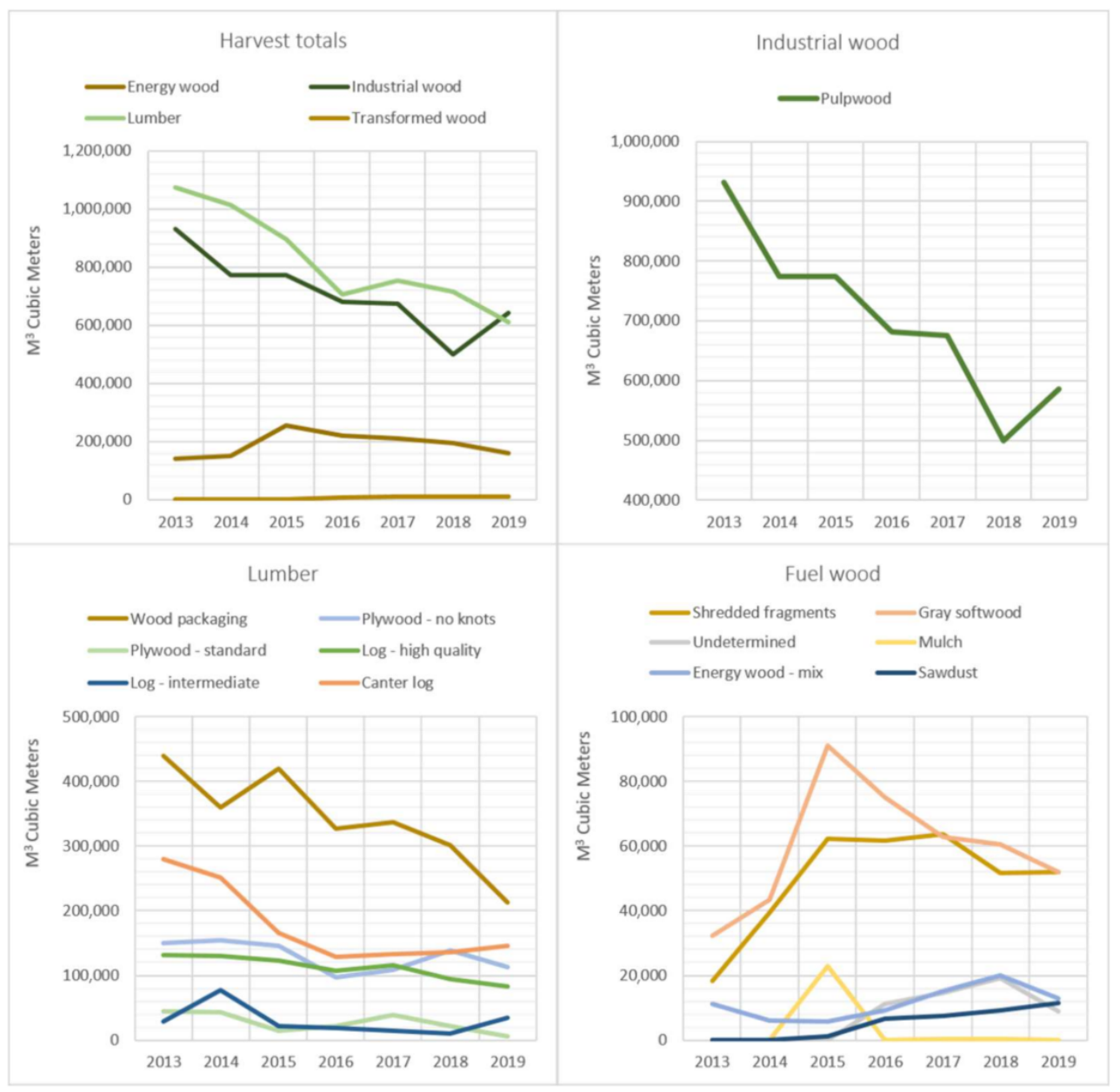

Figure 4. Consolidated harvest totals detailing flows of industrial, energy and lumber wood from 2013 to 2019. 
Wood pulp for packaging, sanitary products and paper segments is increasingly supplied from South America [33]. The overall paper demand declined in the UNECE region (that represents $17 \%$ of the world population and includes European countries, but also countries in North America (Canada and United States), Central Asia (Kazakhstan, Kyrgyzstan, Tajikistan, Turkmenistan and Uzbekistan) and Western Asia (Israel)) by 1.2\%, with packaging and tissue grades partially offsetting the reduced demand for graphic grades-newsprint, printing and writing paper. However, this downward trend was seen in all top paper and board producing countries, primarily due to the EU economy slowing down in 2019-from 1.9\% in 2018 to $1.1 \%$ in 2019 [34]. It is important to note that the EU paper and board production followed this 2019 downward economic trend, in contrast with a significant increase in market pulp production as a result of the export market demand. From 2018, and accelerated with the pandemic crisis, the use of cardboard packaging has increased. According to the Confederation of European Paper Industries (CEPI), exports of market pulp rose close to $40 \%$ in 2019 . This rise can be directly seen in the data analyzed, showing a large increase in pulpwood from 2018 to2019, eliminating a 6-year gradual decrease. To respond to this higher demand, CEPI currently invests 5.5 billion euros annually to increase the production of market pulp and further implement biorefinery concepts, which create highly innovative bio-based products [35].

Softwoods, like maritime pine, are better for paper pulp because the increased fiber length usually translates into more inter-fiber bonding. This increase in bonding generates stronger paper. Furthermore, softwood pulps impart greater strength to the products into which they are made, compared to hardwood pulps manufactured in the same process. The major environmental impacts of producing wood pulp come from its impact on forest sources and from the waste generated [36]. The practice of clear cutting, or removing all trees in a specified sector, is a particularly sensitive issue due to the process being highly visible. Reforestation, or the planting of tree seedlings on logged areas, is also criticized for decreasing biodiversity because reforested areas are monocultures. Furthermore, the logging of old growth forest accounts for $10 \%$ of wood pulp; however, this is one of the more controversial issues in forest harvesting. Current product diversification also shows that the use of maritime pine has changed and expanded compared to past uses. Different parts of the tree now have different industries they are allocated too, i.e., the tops of trees to market pulp and the trunks for building or structural materials. Focusing exclusively on one type of valorization could be dangerous for the potential value and services of the forest in the future.

\subsection{Economic Assessment}

The price of wood normally depends on the ability of using it as solid wood. However, in the case of maritime pine, all harvested wood can potentially be highly valorized by chemical processing, for example, through the distillation of pine resin to generate turpentine. Consequently, for the price of logs delivered in factory, we observed that the different products had similar prices around 0.80 and $1.00 €$ per cubic meter. Thus, there was not a significant variation when assessing the economic flows (including the price and mass) in comparison to the mass flows presented above. The similar prices at this stage of the supply chain are due to yield questions in sawmills and other timber and plywood utilization, although the difference in price of the final products can be significant. Any pricing information used in this study was sourced from AGRESTE website (French statistics on agriculture, agrifood and forest) and not indicative of any profits of pricing data relevant to Alliance Forêts Bois [30].

Currently, pulpwood is the main industrial product which provides the most economic benefit for this region. The lumber wood allocations can be seen with a large emphasis on wood packaging and canter log. Wood packaging, the main economic gain concerning lumber wood, showed a steady decrease from 2013 through 2019. However, canter log showed a positive increase from 2016 to 2019. All other products used for construction, including no-knot plywood and high-quality log had relatively low yield amounts. 
While this paper's primary focus was charting the physical flows of maritime pine from the Landes de Gascogne territory, further work on costing components is necessary to create a strong economic dimension to this research. This can generate conclusions on how to derive further benefit from wood coming out of the forest by focusing on specific products that create added value. There is, of course, a large question of investment into the sawmills from the economic point of view, and how to position maritime pine into diversified economic layers. Therefore, a central goal is to have a higher gross domestic product (GDP) with lower environmental impacts. Furthermore, forest exploitation would ideally remain the same, but the product benefit would be higher, while simultaneously generating lower emissions.

Making the jump to a new market of growth requires an in-depth architecture of predictive decision supports. As economic evolutions continue, it becomes more apparent that timber industries must be flexible in supporting new markets, while also obtaining a more sustainable harvest. Material flow analysis can contribute as a support to regional sustainable development through the cascading and charting of raw materials. Risk must be limited, while economic growth is allowed to evolve and grow in spite of the many factors of disturbance brought on by climate change and market fluctuations.

\subsection{An Improved Regional Assessment}

This work is important to establish a foothold of research on the region, and furthermore, to provide supplementary raw material allocation information for future endeavors. This papers goal was to assess the production of timber in the Landes de Gascogne region on the basis of the material flow analysis (MFA) approach. The MFA approach can help generate future methodologies for decision-making and design, as well as future research perspectives within the context of sustainability and cascading timber product flows. France currently builds its infrastructure with imported wood, primarily from Scandinavia, and imports more wood than it exports. Overall, the French timber industry desires a pivot towards construction, a sector that produces both added value and future employment, while also encouraging the French low-carbon strategy.

When analyzing all individual flows, it can be seen that, on average, there was a 9\% reduction in harvest volume totals from 2013 to 2019 . There was a 33.7\% difference when comparing the volume harvest of 2013 and 2019 in the Landes de Gascogne region. Concerning fuelwood, there were some abnormalities, most likely attributed to variations in supply and demand. There was clearly a dedication to specific industries, namely wood packaging and pulp wood, which can be seen in every harvest year. This is due in part to the overall design of the current territory, species of tree and its dedication, driven by market values in the pulp and paper industry. This design and focus are difficult to transition into a focus on providing more old growth forest and more construction-based products. However, the history of raw timber allocation shows no static norm, and industries must be prepared to evolve in order to expand economic viability to new sectors.

Currently, the French forestry industry employs around 450,000 individuals, while Germany, with a slightly smaller forest area, employs 1.3 million. Proactive policies are required to shape this industry and focus on its future growth in the region. These policies will have to balance the design of the forests in line with future economic added value gain, as well as continue to support social aspects of everyday life. It is important to arrive at a consensus of what type of forest will be generated. A forest that primarily supports industrial and economic viability or a forest that promotes biodiversity. There are ways to build a bridge connecting these types. This balance can be achieved by infrastructure investments towards improving harvesting techniques, and specifically, sawmill advancements.

It is clear that the Landes de Gascogne forest is being primarily utilized for the wood and pulp industry. This means that the harvesting of new growth is primarily fueling economic turnover and profits. However, with the yearly harvest decreasing from 2013, in connection to catastrophic losses from windthrow in 2009, the long-term economic viability 
must be addressed. Young trees, which are more susceptible to wind, are mainly used within the wood pulp and packaging industries. Therefore, raw material valorization and quality are dependent on design and management. This viability could be dependent on the creation of added value products focused in various sectors. Prices for these products are forecasted to remain level in the short-term; therefore, with no added value implemented through the growth of lumber harvest, there is a potential for a diminishing market return for market pulp and cardboard. Furthermore, 11\% of wood was allocated to fuel from 2013 to 2019. This high percentage can likely be decreased with improvements and investments at the sawmill. This amount could also decrease as growing sectors utilize more processed and transformed wood to create added value products through biorefining operations.

Buildings in a sustainable world require strong, highly flexible and light materials, that have also been harvested in a more sustainable way. This has provided good opportunities for the steel sector, although currently, it is also a threat, as more cost-effective substitutes such as composites and cross-laminated timber are being developed. Rapid changes are occuring in technology and also in the economy. This means that only organizations that are flexible will be able to adapt to these changes and succeed. This understanding gives a massive advantage over more rigid organizations. Strong demand for timber resources in a sustainable world makes these materials critical to supporting energy, social and urban needs of a larger, wealthier global population.

\section{Conclusions}

In this paper, we described the evolution of a cultivated forest, subjected to climate change, market fluctuations, human design and management. We described the upstream raw material stocks and flows, from harvested lumber through its valorization in various industries. The results showed that, in a representative period, the valorization of raw materials decreased when the overall quality and amount of high-value timber deteriorated. In light of increasing catastrophic wind storms it should be noted that, the younger the trees, the more susceptible they are to breakage and a lower potential raw material valorization. Generally, the younger the tree, the lower the environmental potential to store carbon. Larger and older trees actively fix higher amounts of carbon compared to smaller trees due to increases in the trees' total leaf area [37].

We can see from the results that this region has a specific upstream input dedicated primarily to pulpwood. With contributing factors, including human design and management, disease, weather events and market fluctuations, a concise supply of raw material designated to deliver short- and long-term economic benefits can be challenging to reach. We saw from the data that certain designs or disturbances lead to a limited industrial use of raw materials, which are designated to highly specific industries and solely deliver shortterm added value at the cost of long-term economic gain. The benefit of harvesting young trees generates revenue within the market pulp global structure, while simultaneously enhancing vulnerabilities from windthrow and other weather events [38].

As timber becomes a more powerful market driver in the construction sector, and as technologies such as cross-laminated timber continue to deliver the ability to build bigger and higher, the growth and development of this region to meet a new product demand will be crucial in the private and public sector. Predictive forest design planning paired with tools like material flow analysis must be supported and implemented considering the current and future market needs in the context of a circular economy.

Author Contributions: Data curation, R.J.L. and R.P.; Formal analysis, R.J.L.; Conceptualization and methodology, R.H.A.; R.P. and G.S.; Investigation, R.J.L. and H.Y.; Software and visualization, R.H.A.; Validation, R.H.A. and R.P.; Writing — original draft preparation, R.J.L. and R.H.A.; Writing-review and editing, R.P. and G.S.; Supervision, G.S.; Project administration, R.P.; Funding acquisition, R.P. and G.S. All authors have read and agreed to the published version of the manuscript.

Funding: This research was funded by the industrial research chair E2WP (Eco engineered Wood Products), EIT RawMaterials-TripleLink project and Campus France-PAUSE program. 
Institutional Review Board Statement: Not Applicable.

Informed Consent Statement: Not Applicable.

Data Availability Statement: Not Applicable.

Acknowledgments: The authors would like to thank Alliance Forêts Bois for the data provided for this research.

Conflicts of Interest: The authors declare no conflict of interest.

\section{References}

1. European Union. Agriculture, Forestry and Fishery Statistics; European Union: Brussels, Belgium, 2019; ISBN 9789279330056.

2. Bellassen, V.; Luyssaert, S. Carbon sequestration: Managing forests in uncertain times. Nature 2014, 506, 153-155. [CrossRef] [PubMed]

3. Alberdi, I.; Bender, S.; Riedel, T.; Avitable, V.; Boriaud, O.; Bosela, M.; Camia, A.; Cañellas, I.; Castro Rego, F.; Fischer, C.; et al. Assessing forest availability for wood supply in Europe. For. Policy Econ. 2020, 111, 102032. [CrossRef] [PubMed]

4. United Nations. Transforming Our World: The 2030 Agenda for Sustainable Development; United Nations: New York, NY, USA, 2015.

5. Siebert, A.; Bezama, A.; O'Keeffe, S.; Thrän, D. Social life cycle assessment indices and indicators to monitor the social implications of wood-based products. J. Clean. Prod. 2018, 172, 4074-4084. [CrossRef]

6. Ioannidou, D.; Pommier, R.; Habert, G.; Sonnemann, G. Evaluating the risks in the construction wood product system through a criticality assessment framework. Resour. Conserv. Recycl. 2019, 146, 68-76. [CrossRef]

7. Massari, S.; Sonnemann, G.; Balkau, F. (Eds.) Life Cycle Approaches to Sustainable Regional Development; Routledge: New York, NY, USA, 2016.

8. Pommier, R.; Grimaud, G.; Prinçaud, M.; Perry, N.; Sonnemann, G. LCA (Life Cycle Assessment) of EVP—Engineering veneer product: Plywood glued using a vacuum moulding technology from green veneers. J. Clean. Prod. 2016, 124, 383-394. [CrossRef]

9. Pommier, R.; Grimaud, G.; Prinçaud, M.; Perry, N.; Sonnemann, G. Comparative environmental life cycle assessment of materials in wooden boat ecodesign. Int. J. Life Cycle Assess. 2016, 21, 265-275. [CrossRef]

10. Bais, A.L.S.; Lauk, C.; Kastner, T.; Erb, K. Global patterns and trends of wood harvest and use between 1990 and 2010. Ecol. Econ. 2015, 119, 326-337. [CrossRef]

11. Budzinski, M.; Bezama, A.; Thrän, D. Monitoring the progress towards bioeconomy using multi-regional input-output analysis: The example of wood use in Germany. J. Clean. Prod. 2017, 161, 11. [CrossRef]

12. Kayo, C.; Dente, S.M.R.; Aoki-Suzuki, C.; Tanaka, D.; Murakami, S.; Hashimoto, S. Environmental Impact Assessment of Wood Use in Japan through 2050 Using Material Flow Analysis and Life Cycle Assessment. J. Ind. Ecol. 2019, 23, 635-648. [CrossRef]

13. European Commission. A New EU Forest Strategy: For Forests and the Forest-Based Sector; European Commission: Brussels, Belgium, 2013; pp. 1-17.

14. Mehr, J.; Vadenbo, C.; Steubing, B.; Hellweg, S. Environmentally optimal wood use in Switzerland-Investigating the relevance of material cascades. Resour. Conserv. Recycl. 2018, 131, 181-191. [CrossRef]

15. Mubareka, S.; Vacchiano, G.; Pilli, R.; Hilferink, M.; Fiorese, G. Integrated modelling approach to assess woody biomass supply, demand and environmental impacts of forest management in the EU. In Proceedings of the 9th International Congress on Environmental Modelling and Software, Ft. Collins, CO, USA, 24-28 June 2018.

16. Mitchell, S.J. Wind as a natural disturbance agent in forests: A synthesis. Int. J. For. Res. 2012, 86, 147-157. [CrossRef]

17. European Commission. Guidance on Cascading Use of Biomass with Selected Good Practice Examples on Woody Biomass; European Commission: Brussels, Belgium, 2018; ISBN 9789279931536.

18. Budzinski, M.; Bezama, A.; Thrän, D. Estimating the potentials for reducing the impacts on climate change by increasing the cascade use and extending the lifetime of wood products in Germany. Resour. Conserv. Recycl. 2020, 6, 100034. [CrossRef]

19. Mantau, U. Wood flow analysis: Quantification of resource potentials, cascades and carbon effects. Biomass Bioenergy 2015, 79, 28-38. [CrossRef]

20. Lenglet, J.; Courtonne, J.Y.; Caurla, S. Material flow analysis of the forest-wood supply chain: A consequential approach for log export policies in France. J. Clean. Prod. 2017, 165, 1296-1305. [CrossRef]

21. Institut National de l'Information Géographique et Forestière. Le mémento: Inventaire Forestier; IGN (Institut National de l'Information Géographique et Forestière): Saint Mandé, France, 2019.

22. Hautdidier, B.; Banos, V.; Deuffic, P.; Sergent, A. 'Leopards' under the pines: An account of continuity and change in the integration of forest land-uses in Landes de Gascogne, France. Land Use Policy 2018, 79, 990-1000. [CrossRef]

23. Brunner, P.; Rechberger, H. Practical Handbook of Material Flow Analysis; CRC Press: Boca Raton, FL, USA, 2003.

24. Graedel, T.E. Material Flow Analysis from Origin to Evolution. Environ. Sci. Technol. 2019, 53, 12188-12196. [CrossRef]

25. Schwab, O.; Zoboli, O.; Rechberger, H. A Data Characterization Framework for Material Flow Analysis. J. Ind. Ecol. 2017, 21, 16-25. [CrossRef]

26. Patrício, J.; Kalmykova, Y.; Rosado, L.; Lisovskaja, V. Uncertainty in material flow analysis indicators at different spatial levels. J. Ind. Ecol. 2015, 19, 837-852. [CrossRef] 
27. Bösch, M.; Jochem, D.; Weimar, H.; Dieter, M. Physical input-output accounting of the wood and paper flow in Germany. Resour. Conserv. Recycl. 2015, 94, 99-109. [CrossRef]

28. Weimar, H. Der Holzfluss in der Bundesrepublik Deutschland 2009. Methode und Ergeb-nis der Modellierung des Stoffflusses von Holz. In Tech. Rep. Arbeitsbericht; von Thunen, J.H., Ed.; Institut fur Forst- undHolzwirtschaft: Hamburg, Germany, 2009.

29. Fonseca, M. Paper 49: Forest Product Conversion Factors for the UNECE Region. Geneva Timber For. Discuss. Pap. 2010, 49, 1-50.

30. Schmidt, M. The Sankey Diagram in Energy and Material Flow. J. Ind. Ecol. 2008, 12, 82-94. [CrossRef]

31. Agreste Database-Wood harvesting in France. Available online: www.agreste.agriculture.gouv.fr.

32. Pommier, R.; Breysse, D.; Garbay, G. Modeling the distribution of the variability of maritime pine for wooden sawn timber and finger jointing. Eur. J. Environ. Civ. Eng. 2014. [CrossRef]

33. FAO. State of the World's Forests 2014: Enhancing the Socioeconomic Benefits from Forests; FAO: Rome, Italy, 2014; ISBN 978-92-5-108269-0.

34. European Comission. Autumn 2019 European Economic Forecast; European Commission: Brussels, Belgium, 2019.

35. CEPI. Report of the Confederation of European paper industries. In Key Statistics 2019: European Pulp and Paper Industry; Confederation of European Paper Industries: Brussels, Belgium, 2019; pp. 1-32.

36. González-García, S.; Berg, S.; Feijoo, G.; Moreira, M.T. Environmental impacts of forest production and supply of pulpwood: Spanish and Swedish case studies. Int. J. Life Cycle Assess. 2009, 14, 340-353. [CrossRef]

37. Stephenson, N.; Das, A.; Condit, R.; Russo, S.E.; Baker, P.J.; Beckman, N.G.; Coomes, D.A.; Lines, E.R.; Morris, W.K.; Rüger, N.; et al. Rate of tree carbon accumulation increases continuously with tree size. Nature 2014, 507, 90-93. [CrossRef] [PubMed]

38. Beaussier, T.; Caurla, S.; Bellon-Maurel, V.; Loiseau, E. Coupling economic models and environmental assessment methods to support regional policies: A critical review. J. Clean. Prod. 2019, 216, 408-421. [CrossRef] 